\title{
Virus Movement from Infected Sweetpotato Vines to Roots and Reversion on Root Sprouts
}

\author{
Scovia Adikini ${ }^{1}$ and Settumba B. Mukasa \\ School of Agricultural Sciences, Makerere University, P.O. Box 7062, \\ Kampala, Uganda \\ Robert O.M. Mwanga \\ International Potato Center, P.O. Box 22274, Kampala, Uganda \\ Richard W. Gibson \\ Natural Resources Institute, University of Greenwich, Medway Campus, \\ Central Avenue, Chatham Maritime, Kent ME4 4TB, UK
}

Additional index words. sweetpotato, seed roots, symptom expression, virus infection, sweetpotato virus disease

\begin{abstract}
Sweetpotato is usually propagated in Uganda by vine cuttings from mature crops, but sometimes sprouts from storage roots are used, especially in drought-prone areas. No information is available on whether the storage of roots of Ugandan cultivars are infected with the viruses and whether the sprouts on them express symptoms so that farmers can eliminate diseased ones. Information on root sprout reversion from virus infection is also lacking. The storage roots of five sweetpotato cultivars was sourced either by random selection of roots from already harvested roots or obtained from symptomless plants selected before harvest at Makerere University Agricultural Research Institute, Kabanyolo (MUARIK), and the National Semi Arid Resources Research Institute (NaSARRI). Roots were also generated in a screenhouse after being inoculated with Sweet potato feathery mottle virus (SPFMV) and/or Sweet potato chlorotic stunt virus (SPCSV). More than $70 \%$ of sprouts from roots of all the cultivars selected after harvest at MUARIK and NaSARRI were infected with the viruses. For roots obtained from symptomless plants, $64 \%$ and $21 \%$ of the sprouted roots from MUARIK and NaSARRI were infected with the viruses, respectively. Most of the root samples from MUARIK had visible virus symptoms on sprouts and tested positive for both SPFMV and SPCSV, whereas those from NaSARRI did not show symptoms and were infected primarily with SPFMV. Plants graft-inoculated with either SPCSV or SPFMV alone produced both infected and noninfected roots, whereas all the root sprouts from dually infected plants showed virus symptoms. Reversion from virus infection was observed on root sprouts infected singly with SPFMV, whereas those infected with SPCSV showed recovery only, and none of the root sprouts infected by both viruses showed recovery. This study proves that roots are good reservoirs for viruses, and reversion occurs only when singly infected with SPFMV. Therefore, there is a need to establish seed channels in which seedstock is cleaned continuously and made available to farmers.
\end{abstract}

Sweetpotato propagation in Uganda usually involves the use of vine cuttings from mature crops obtained from a farmer's own gardens or from neighbors' (Bashaasha et al., 1995, Gibson et al., 2009). This, however, may not be the case in areas with a long dry season in which the existing sweetpotato fields dry out, resulting in lack of planting material at the onset of the rain (Gibson et al.,

Received for publication 17 July 2018. Accepted for publication 14 Oct. 2018.

This research was supported by the International Potato Center (CIP) through the Sweetpotato Action for Security and Health in Africa (SASHA) project as part of the Consultative Group for International Agricultural Research (CGIAR) Research Program on Roots, Tubers and Bananas (RTB).

${ }^{1}$ Corresponding author. E-mail: adikiniscovia@ gmail.com.
2011). Most farmers in such areas tend to wait for the surviving roots in the soil to sprout to obtain planting materials, leading to late planting (Gibson et al., 2009; Namanda et al., 2011, 2012; Yanggen and Nagujja, 2006). The health status of such sprouts is not known; but, if infected by virus, they may act as a local source of inoculum from which insect vectors can quickly spread it. This may result in virus accumulation and perpetuation over generations, thus reducing sweetpotato quality and yield (Gibson et al., 2009; Karyeija et al., 1998).

To overcome the challenge of late planting by ensuring timely access to planting material in areas prone to drought, a method of sprouting storage roots has been developed (Namanda, 2012) and is being promoted in Uganda, Tanzania, and Malawi by the International Potato Center (CIP). The source of seed roots used by farmers for this tech- nology is from their commercial fields and, in most cases, farmers do the selection after harvesting the entire field, implying that the health status of the mother plants of selected roots is not known. Some farmers may even get roots from neighbors or marketplaces and use them to generate planting materials. A major limitation with this method of using storage roots as a source of planting material is that little or no information is available on the virus status of the storage roots, and therefore the decision about which root to save as seed is difficult.

SPFMV (family, Potyviridae; genus, Potyvirus) and SPCSV (family Closteroviridae; genus, Crinivirus) are the major economically important sweetpotato viruses in Uganda, although other viruses such as Sweet potato mild mottle virus (family, Potyviridae; genus, Ipomovirus), Sweet potato caulimolike virus (family, Caulimoviridae; genus, Cavemovirus), Sweet potato chlorotic fleck virus, and Sweet potato leaf curl Uganda virus (family, Geminiviridae; genus, Begomovirus) have also been reported (Aritua et al., 2000, 2007; Mukasa et al., 2003; Ndunguru et al., 2009; Wasswa et al., 2011). Single infection by these viruses causes mild or no foliar symptoms, and this has made selection against infected material difficult, leading to their continued use. However, vines infected by a single virus, especially SPFMV, have been reported to revert to a healthy status (Gibson et al., 2014).

Reversion is a phenomenon whereby virus-infected plants naturally become healthy through the mechanism of gene silencing (Gibson et al., 2014). Reversion has been reported in cassava from Cassava mosaic geminiviruses (family, Geminiviridae; genus, Begomovirus) and has been exploited in the management of this virus (Fargette et al., 1994; Gibson and OtimNape, 1997). In sweetpotato, however, reversion from SPFMV has been reported In landraces from East Africa (e.g., Tanzania and New Kawogo) and locally bred varieties (e.g., 'NASPOT 11'), but not with exotic varieties (Aritua et al., 1998; Wasswa, 2012, Gibson et al., 2014). This could be the reason why sweetpotato farmers in Uganda have continued to use symptomless vines successfully from their fields without serious sweetpotato virus disease (SPVD) infection. In all the reversion studies done so far, the focus has been on SPFMV, and they are limited to vine materials only. It is not clear whether plants infected by SPCSV alone or sprouts from infected roots can recover and/or revert from virus infection.

Coinfection of SPFMV and SPCSV results in severe disease symptoms characterized by a combination of vein clearing, chlorosis, leaf purpling, mosaic, leaf distortion, mottling, and complete plant stunting, which is described as SPVD (Gibson et al., 1998; Gutierrez et al., 2003; Milgram et al., 1996). These clear symptoms make it easy for a farmer to select against such vines when sourcing for planting materials. It is, however, not known whether the storage roots derived from infected vines among the 
Ugandan cultivars can produce symptomatic sprouts to enable farmers to rogue during the time of sprouting in screenhouses before field planting or, if infected, whether they too can revert to a healthy status. In some US sweetpotato cultivars such as Beauregard, when infected singly with the russet crack strain of SPFMV, the roots show external cracking and internal "corkiness," and when planted, the virus symptoms on sprouts are very clear, making it easier to select against such roots (Clark and Moyer, 1988; Gutierrez et al., 2003). Infection by other strains of SPFMV, as well as Sweet potato virus $C$, Sweet potato virus $G$, and Sweet potato virus 2 are also common in the United States and cause yield losses without causing readily discernible symptoms on roots. Thus, the problem is common wherever sweetpotatoes are grown. This study was designed to determine whether viruses (single or mixed infection) can move from infected vines to storage roots, then express symptoms on the sprout, and to determine whether the infected sprout can revert to a healthy one.

\section{Materials and Methods}

Sweetpotato cultivars used. Five sweetpotato cultivars were used in this study. Beauregard is an exotic cultivar from the United States. Its roots are orange-fleshed and is very susceptible to SPVD (Clark and Hoy, 2006). 'Dimbuka-Bukulula' is a landrace, with cream root flesh, and is moderately susceptible to SPVD. This cultivar is grown in all sweetpotato growing regions of Uganda (Mwanga et al., 2007). Cultivar Ejumula is a landrace with orange root flesh and it is susceptible to SPVD. It is also widely grown in Uganda (Mwanga et al., 2007). NASPOT 1 is a research station-bred cultivar with a white flesh root, and it is resistant to SPVD. It too has been widely adopted by farmers in most sweetpotato growing areas of Uganda (Mwanga et al., 2003). Kabode (also called NASPOT $10 \mathrm{O}$ ) is a station-bred orange flesh variety that is widely grown by most farmers in Uganda. It is moderately resistant to SPVD.

Sources of roots. Roots used in this study were either sourced from the field or generated in the screenhouse. Roots sourced from the field were of two categories roots selected randomly from already harvested sweetpotato and roots obtained from symptomless plants selected before harvesting. These two root sources were obtained from two locations: MUARIK, in the Wakiso District, which represents regions with high SPVD pressure; and NaSARRI, in Serere District, which represents regions with low SPVD pressure. The third root source was generated by planting sweetpotato vines and graftinoculating them with viruses under screenhouse conditions at MUARIK

Sweetpotato roots selected from previously harvested sweetpotato as a source of planting material in areas with high and low disease pressure. In this trial, sweetpotato roots sourced from two locations, MUARIK and NaSARRI, were evaluated. The roots were selected from among previously harvested ones and at random, with the roots showing no damage or defects. Thirty roots of four cultivars-NASPOT 1, Ejumula, DimbukaBukulula, and Beauregard-were selected. The roots were planted in 5-L plastic pots filled with a mixture of soil, sand, and animal manure in equal proportions; arranged according to a randomized complete block design; and allowed to sprout under screenhouse conditions. One month after sprouting, a visual assessment of the sprouts for virus symptom was made and disease incidence was recorded. The root sprouts were tested using nitrocellulose membrane (NCM)-enzymelinked immunosorbent assay (ELISA) to detect and identify some of the viruses present in the roots. The symptomless root sprouts were wedge-grafted on I. setosa and then tested with NCM-ELISA to rule out the possibility of latent infection.

Roots sourced from symptomless plants selected before harvesting. The second source of roots was obtained by selecting mounds with symptomless plants for each cultivar before harvesting in two locations (MUARIK and NaSARRI). The selected plants were harvested and 40 roots per cultivar with no physical damage were obtained from each location and planted as described earlier. In this trial, three sweetpotato cultivars-NASPOT 1, DimbukaBukulula, and Ejumula-were sampled. One month after sprouting, the roots were assessed for virus symptoms through visual observation, and the viruses present were confirmed using NCM-ELISA. The number of root sprouts and number of plants showing symptoms were recorded.

Reaction of sweetpotato cultivars to virus infection, and generation of sweetpotato roots under screenhouse conditions. Virusindexed sweetpotato cultivars DimbukaBukulula, Ejumula, Kabode, and NASPOT 1 were planted in a screenhouse. Twenty cuttings of each cultivar ( 80 cuttings in total) were planted in a pot containing a mixture of soil, sand, and animal manure in equal proportions. Plants were left to grow for 1 month and were graft-inoculated with appropriate virus inoculum using the wedge grafting method (Mwanga et al., 2013). Before inoculation, each cultivar was divided into four groups each of five plants. One group was graft-inoculated with SPFMV, a second group was graft-inoculated with SPCSV, a third group was graft-inoculated with a combination of SPFMV + SPCSV, and a fourth group was mock-inoculated as controls. These plants were allowed to grow for 4 months, during which their response to virus infection was monitored. The grafted plants were also tested by grafting their shoots to indicator plants of I. setosa; NCM-ELISA was used to confirm the presence of the viruses. After 4 months, the roots were harvested and their weight recorded. The harvested roots were then sprouted to evaluate whether the virus moved from the infected shoot to the root. This experiment was repeated two times.
Evaluation of virus movement from roots to sprouts. The harvested roots referred to earlier were evaluated to determine whether roots from infected plants can produce infected sprouts. In this trial, 10 roots from each treatment per cultivar were planted in pots containing equal proportions of sand, soil, and manure, and were allowed to sprout under screenhouse conditions. One month after sprouting, the root sprouts were assessed for the number of shoots produced and the virus symptoms expressed. The symptomatic plants were tested by double antibody sandwich (DAS) and triple antibody sandwich (TAS) ELISA to confirm whether symptoms expressed were the result of virus infection. Also, asymptomatic shoots were grafted on I. setosa to rule out latent infection. The sprouted shoots were allowed to grow for 4 more months in a screenhouse, during which time progress on symptom expression and severity were monitored. At five months before the termination of the experiment, the shoots were grafted onto $I$. setosa and also tested by ELISA to determine whether there was any reversion.

Virus detection and quantification by ELISA. Two types of virus tests were used. One involved grafting sweetpotato vines on $I$. setosa seedlings and observing whether symptoms developed. This was considered to be a very sensitive test for virus infection, but relatively poor at identifying which virus was involved. The second type involved ELISA tests, which identified the specific virus involved. Three ELISA methods were used: NCM-, DAS-, and TAS-ELISA. NCMELISA was conducted to detect and identify the viruses present in the sprouts from fieldderived roots. A standard protocol for an NCM-ELISA kit obtained from CIP, Lima, was followed and the results were based on visual assessment of the color change. DASand TAS-ELISA were used to detect and estimate the virus load resulting from SPFMV and SPCSV in the samples according to the protocol by Clark and Adams (1977). The DAS-ELISA kit [containing coating antibody immunoglobulin $\mathrm{G}$ ( $\mathrm{IgG}$ ) and detecting antibody IgG-alkaline phosphatase (AP)] against SPFMV and the TASELISA kit (containing primary antibody, rabbit IgG, secondary mouse monoclonal antibody and detection antibody, rabbit antimouse IgG-AP against SPCSV, and respective positive controls) were from LeibnizInstitut DSMZ-Deutsche sammlung von Mikroorganismen und Zellkuturen $\mathrm{GmbH}$, Braunschweig, Germany. The $p$-nitro phenyl phosphate substrate and microplates used were from Sigma Chemical Co. Absorbance was measured at $405 \mathrm{~nm}$ after $1.5 \mathrm{~h}$ using a Bio-Rad microplate reader (model 680; BioRad).

\section{Results}

Effects of selecting roots randomly from already harvested sweetpotato as a source of planting material from high and low virus pressure areas. Sprouts from sweetpotato 
roots selected randomly after field harvesting from MUARIK all developed virus symptoms (Fig. 1A-C) except a few roots of 'Dimbuka-Bukulula'. The symptoms observed were combinations of vein clearing, mosaic, distorted leaf shape, and stunted growth. These symptomatic root sprouts, when tested using NCM-ELISA, mostly reacted positively for both SPFMV and SPCSV (Table 1). In addition, the sprouting capacity of some roots was poor, especially for cultivar Dimbuka-Bukulula at MUARIK (Table 1), for which only 19 roots $(63 \%)$ sprouted; the rest of the roots were rotten. At NaSARRI, however, the sprouting capacity of roots was more than $90 \%$ in all the cultivars tested (Table 1). For sweetpotato roots from NaSARRI obtained after field harvest, no virus symptoms were visible on the sprouts of 'NASPOT 1', 'DimbukaBukulula', and 'Ejumula' (Fig. 1D-F). The exception was in cultivar Beauregard, in which all the root sprouts developed typical virus symptom that, when tested by NCMELISA, indicated the presences of both SPFMV and SPCSV. Some of the symptom- less sprouts, when grafted onto I. setosa, developed characteristic feathery mottle symptoms (Fig. 1G-I), and the virus was confirmed with ELISA.

Effects of preselecting sweetpotato roots as source of planting material from unharvested symptomless plants in locations with high and low disease pressure. In this trial in which sweetpotato roots were obtained from symptomless plants, most of the sprouted shoots for cultivar NASPOT 1 and Dimbuka-

Bukulula obtained from MUARIK were symptomless, whereas for 'Ejumula', all the
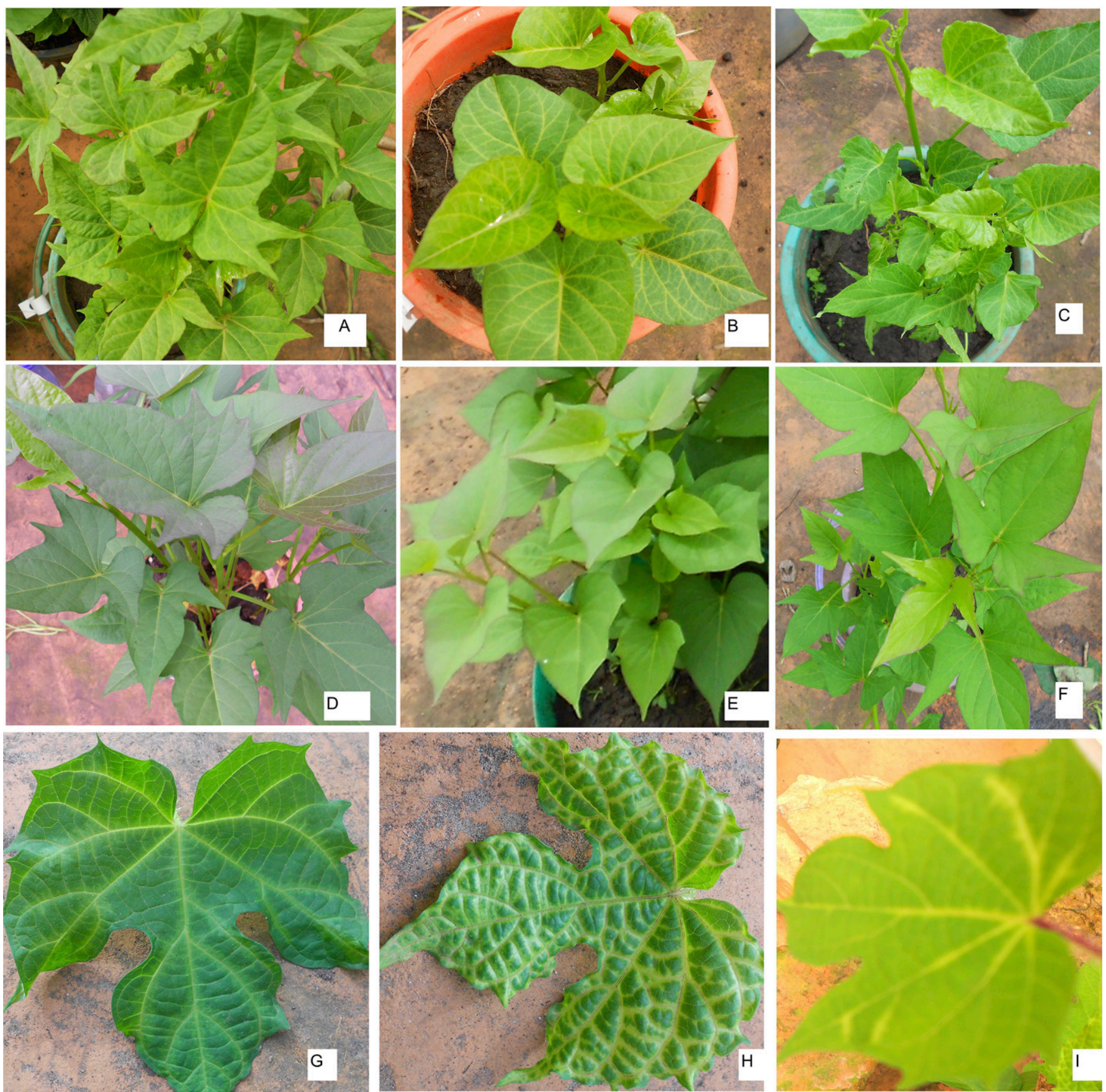

Fig. 1. Virus symptoms expressed on root sprouts from randomly selected roots and on I. setosa after graft inoculation of asymptomatic root sprouts. (A) Symptomatic root sprout of 'NASPOT 1' from Makerere University Agricultural Research Institute, Kabanyolo (MUARIK). (B) Symptomatic root sprout of 'Dimbuka-Bukulula' from MUARIK. (C) Symptomatic root sprout of 'Ejumula' from MUARIK. (D) Asymptomatic root sprout of 'NASPOT 1' from the National Semi Arid Resources Research Institute (NaSARRI). (E) Asymptomatic root sprout of 'Dimbuka-Bukulula' from NaSARRI. (F) Asymptomatic root sprout of 'Ejumula' from NaSARRI. (G) Vein clearing. (H) Vein banding/mottling. (I) Vein chlorosis. 
sprouts developed virus symptoms (Table 2). When the symptomless sprouts were grafted onto I. setosa and tested by ELISA, 43\% of 'Dimbuka-Bukulula', $50 \%$ of 'NASPOT 1', and $100 \%$ 'Ejumula' were infected with a single or a combination of viruses, mainly SPFMV and SPCSV. For the NaSARRI samples, none of the root sprouts were symptomatic and, when grafted onto $I$. setosa and tested with ELISA, $25 \%$ of 'Ejumula', 20\% of 'DimbukaBukulula', and $17 \%$ of 'NASPOT 1' tested positive for SPFMV only (Table 2). Some root sprouts of 'NASPOT 1' (Fig. 2A) developed leaves that did not resemble the parent plants, yet when grafted onto I. setosa, no viral symptoms were observed and, when tested with ELISA, none of the samples reacted positively.

Reaction of sweetpotato cultivars to virus infection and its effect on yield after graft inoculation under screenhouse conditions. In a screenhouse environment, the cultivars reacted to different viruses or a combination of viruses by expressing varied symptoms. For plants infected by SPFMV alone, the symptoms were generally mild in most of the cultivars tested, and sometimes no symptoms were observed, especially in cultivar Kabode. These symptoms later disappeared in all the cultivars, with the subsequent leaves growing normally as in healthy plants. For plants infected by SPCSV alone, the symptoms started by showing interveinal chlorosis that later turned to purple or red spots on mature leaves depending on the cultivar. For dually infected plants, there was a mixture of symptoms characterized by vein chlorosis, purple spots on the leaf, mosaic, and leaf distortion, and the leaves became small and plants were stunted.
In addition to foliar symptoms, these viruses all reduced the root yield of all cultivars significantly in both single and dual infections (Table 3 ). The greatest yield reduction was observed in plants infected by both SPFMV and SPCSV, followed by the plants infected singly by SPCSV, and least in plants infected by SPFMV alone. Among the cultivars tested, NASPOT 1 had the greatest yield, followed by Kabode and Ejumula; Dimbuka-Bukulula had the least yield (Table 3).

Evidence of virus movement into storage roots and root sprouts after infection by SPFMV and SPCSV under screenhouse conditions. Sprouts of roots were assessed visually for the presence of virus symptoms. For roots derived from plants infected with SPFMV, cultivar Ejumula had the greatest number of root sprouts that expressed symptoms, followed by Dimbuka-Bukulula and NASPOT 1. No symptoms were observed in all the root sprouts of cultivar Kabode (Fig. 3). Symptom severity was very mild, with no symptoms observed within the first month after planting (MAP). As time progressed, from the second month, mild symptoms characterized by mild purpling of the margin or mild chlorotic spots on the lower leaves were observed in 'Ejumula', 'Dimbuka-Bukulula' and 'NASPOT 1', but none in 'Kabode'. These symptoms disappeared as time progressed and, by the fifth month after planting (MAP), most sprouts did not have symptoms (Fig. 4) and the shoots grew normally, as did the healthy control plants.

For roots derived from SPCSV-infected plants, the virus incidence was greater in 'Ejumula', followed by 'Dimbuka-Bukulula',

Table 2. Number of roots derived from symptomless plants before harvest that tested positive for different viruses using nitrocellulose membrane-enzyme-linked immunosorbent assay (NCM-ELISA).

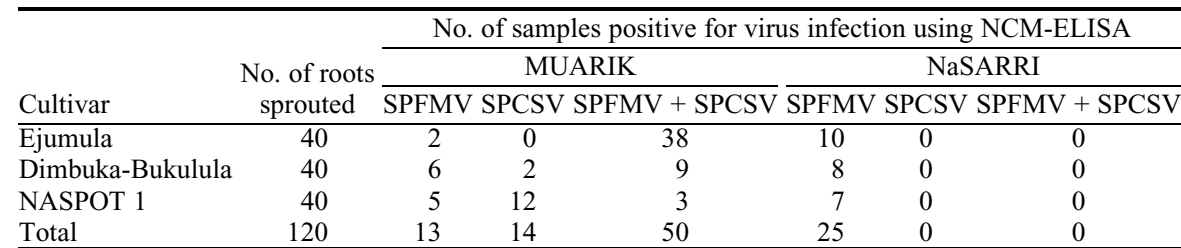

MUARIK, Makerere University Agricultural Research Institute, Kabanyolo; NaSARRI = National Semi Arid Resources Research Institute.
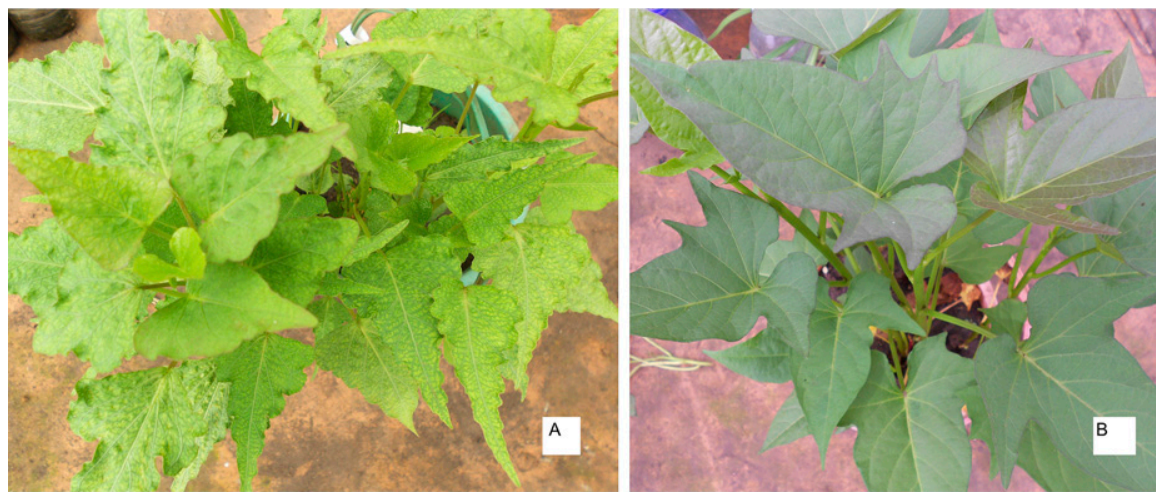

Fig. 2. Sweetpotato root sprout of 'NASPOT 1' showing deviation of leaf morphology from normal. (A) 'NASPOT 1' with interveinal chlorosis and distorted leaf shape. (B) Normal 'NASPOT 1' leaves. 
Table 3. Yield of four sweet potato cultivars from plants that were graft-inoculated with single or combination of Sweetpotato feathery mottle virus (SPFMV) and Sweetpotato chlorotic stunt virus (SPCSV) in a screenhouse environment.

\begin{tabular}{lcccc}
\hline & \multicolumn{4}{c}{ Total yield per plant $(\mathrm{g})$} \\
\cline { 2 - 4 } Virus & Ejumula & Kabode & Dimbuka-Bukulula & NASPOT 1 \\
\hline Trial 1 & $48.3 \mathrm{a}$ & $70.0 \mathrm{~b}$ & $112.4 \mathrm{a}$ & $80.4 \mathrm{a}$ \\
Healthy & $29.7 \mathrm{~b}$ & $86.6 \mathrm{a}$ & $25.8 \mathrm{~b}$ & $60.0 \mathrm{~b}$ \\
SPFMV & $26.7 \mathrm{~b}$ & $27.1 \mathrm{c}$ & $19.2 \mathrm{~b}$ & $48.5 \mathrm{c}$ \\
SPCSV & $21.7 \mathrm{~b}$ & $9.7 \mathrm{~d}$ & $18.6 \mathrm{~b}$ & $52.6 \mathrm{bc}$ \\
SPVD & 31.6 & 48.3 & 44.0 & 60.4 \\
Total mean yield & & & & $112.4 \mathrm{a}$ \\
Trial 2 & $95.3 \mathrm{ab}$ & $76.5 \mathrm{a}$ & $60.2 \mathrm{a}$ & $87.0 \mathrm{~b}$ \\
Healthy & $104.8 \mathrm{a}$ & $64.9 \mathrm{a}$ & $68.6 \mathrm{a}$ & $84.4 \mathrm{~b}$ \\
SPFMV & $80.5 \mathrm{~b}$ & $66.6 \mathrm{a}$ & $62.0 \mathrm{a}$ & $59.1 \mathrm{c}$ \\
SPCSV & $46.2 \mathrm{c}$ & $32 \mathrm{~b}$ & $39.9 \mathrm{~b}$ & 85.7 \\
SPVD & 81.7 & 60.0 & 57.7 & \\
Total mean yield & & & & \\
\hline
\end{tabular}

Means within a column followed by the same letter for each trial are not significantly different $(P<0.05)$ according to Fisher's protected least significant difference.

SPVD $=$ sweetpotato virus disease.

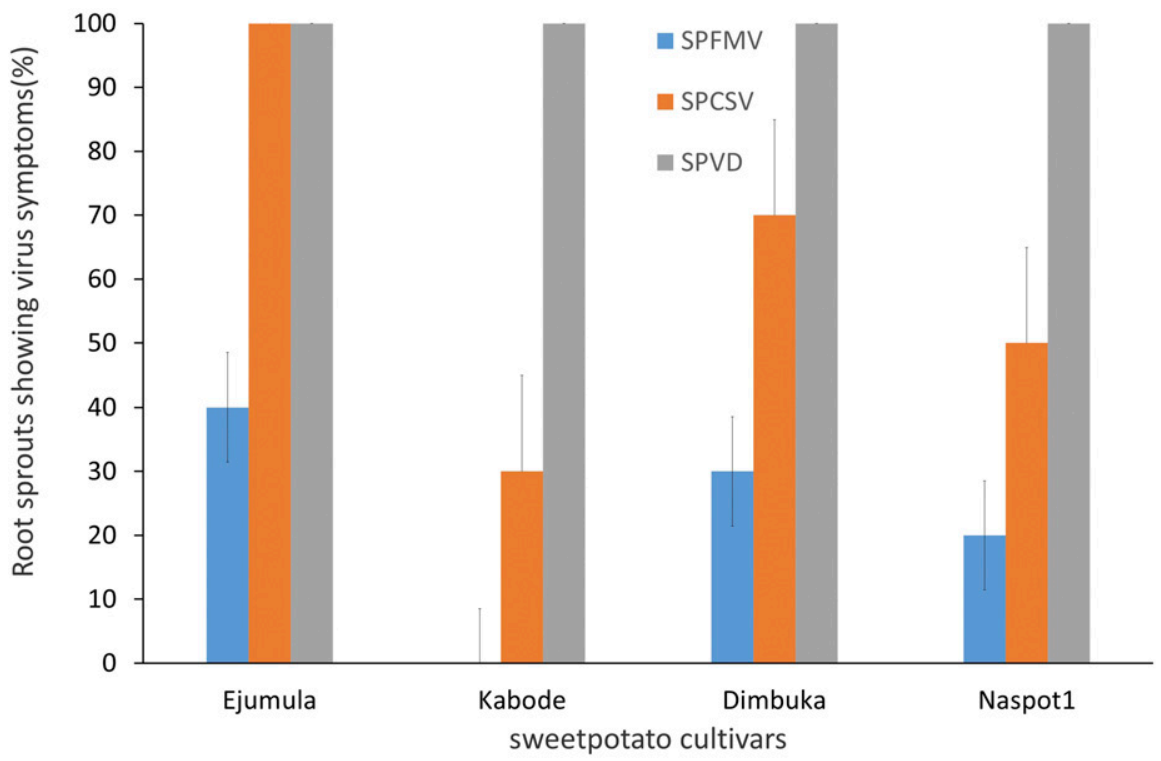

Fig. 3. Percentage of sweetpotato root sprouts expressing virus symptoms from roots derived from plants graft-inoculated with Sweetpotato feathery mottle virus (SPFMV), Sweetpotato chlorotic stunt virus (SPCSV), and their combination for the four different sweetpotato cultivars. SPVD, sweetpotato virus disease.

'NASPOT 1' and 'Kabode' (Fig. 3). Disease severity, however, was low at the beginning of sprouting (1 MAP), but as time progressed, disease severity increased in all the cultivars, with Ejumula having the greatest mean severity score (3.5) at 3 MAP; the rest of the cultivars had mild symptoms, with mean severity scores of 2.0 or less (Fig. 4). The symptoms were mainly leaf purpling and chlorotic spots on mature leaves (Fig. 5)

For roots obtained from plants infected with a combination of SPFMV + SPCSV, all the sprouted shoots were symptomatic in all the cultivars (Fig. 3). The symptoms were very clear from the time of sprouting, with disease severities of more than 3.0, and remained visible throughout for all the cultivars tested (Fig. 4). In some cases, the symptoms became more severe, leading to the death of some sprouts. The symptoms were characterized by vein chlorosis, mosaic, leaf purpling, distorted leaf shape, and stunted growth (Fig. 6).
Detection of SPFMV or SPCSV on the storage root sprouts of four sweetpotato cultivars using ELISA. After the visual assessment of the sprouts, three leaf samples were collected from each root and subjected to ELISA to confirm the presence of viruses. Of the 40 samples tested for SPFMV, 20 were positive for the virus. Most of the samples that tested positive for the virus were from cv. Ejumula, followed by Dimbuka-Bukulula, NASPOT 1 and Kabode (Table 4). For root sprouts infected singly with SPCSV, of the 40 samples tested, only 16 were positive. Again, cv. Ejumula had the most samples testing positive, followed by Dimbuka-Bukulula and then by Kabode and NASPOT 1. For dually infected root sprouts, all 40 samples tested for all cultivars were positive for SPFMV and SPCSV (Table 4).

Virus titer and reversion of storage root sprouts from single infection by SPFMV or $S P C S V$. Virus titer was measured at 2 MAP and at 5 MAP using DAS-ELISA for
SPFMV and TAS-ELISA for SPCSV. The virus titer for SPFMV 2 MAP was greater than the titer at 5 MAP for all cultivars tested. SPFMV titer was greater in cultivar Ejumula, followed by NASPOT 1, and was least in Kabode and Dimbuka-Bukulula (Table 5). At 5 months, all the cultivars showed reversion, with 'NASPOT 1' and 'Kabode' showing greater reversion rates, as evidenced by the low virus titer (Table 5). Cultivars Ejumula and Dimbuka-Bukulula had low reversion rate from SPFMV infection as the virus titer remained relatively high. For SPCSV-infected root sprouts, the virus titer was greater at $2 \mathrm{MAP}$, whereas at 5 MAP, there was a reduction in virus titer in all cultivars. Reversion of root sprouts from SPCSV infection was less compared with that of SPFMV infection. Among the cultivars tested, Ejumula had the greatest SPCSV titer, followed by NASPOT 1, Dimbuka-Bukulula, and Kabode (Table 5). At 5 months, there was a slight reduction in SPCSV titer in all cultivars tested, implying a low reversion rate.

Effect of SPFMV and SPCSV on the number of storage root sprouts produced. A comparison of the number of sprouted shoots produced by each virus treatment per cultivar indicated no significant virus effect on the number of sprouts produced (Table 6) except for cultivar Dimbuka, in which SPFMVinfected roots produced greater sprouts whereas roots infected by both viruses had less sprouts (Table 6).

\section{Discussion}

Use of sweetpotato storage roots as a source of planting material has not been a formal practice in Uganda until a recent study by Namanda (2012) was published that described a sand storage and root sprouting method for rapid multiplication of sweetpotato planting material in dry areas. Although this technology is under promotion in Uganda, Tanzania, and Malawi, little has been done to understand virus epidemiology in storage roots of local cultivars. In other countries like the United States, where roots are the major source of planting material, sweetpotato viruses are known to infect and spread through the roots. However, in Uganda, most sweetpotato cultivars are known to revert to healthy plants when infected with SPFMV (Gibson et al., 2014). Therefore, it was worthwhile to determine whether these viruses can infect the roots and express symptoms on the sprouts. In this study, roots obtained from farmers' naturally infected fields and those obtained from plants graft-inoculated with viruses in the screenhouse both developed symptoms on their sprouts, although the extent of symptom expression was dependent on the cultivar and the infecting virus. The symptoms expressed were confirmed as being caused by either SPFMV, SPCSV, or both viruses using serology, which provided clear evidence that these viruses move from the infected vine to roots and then to sprouts of the Ugandan local cultivars. For sprouts infected singly by either SPFMV or SPCSV, the 

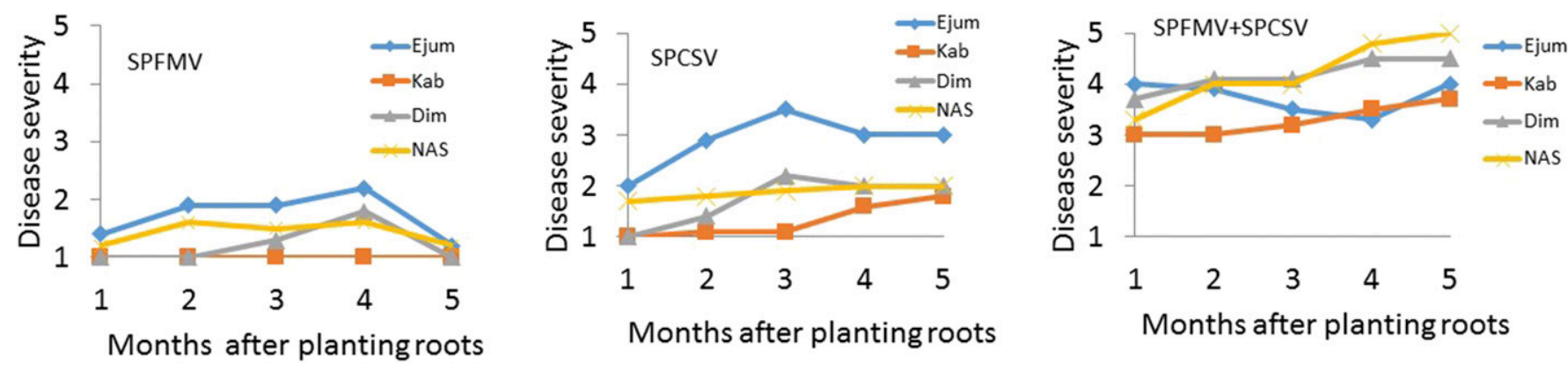

Fig. 4. Progress in disease severity resulting from virus infection on root sprouts of four sweetpotato cultivars over time under screenhouse conditions. Ejum, 'Ejumula'; Kab, 'Kabode'; Dim, 'Dimbuka-Bukulula'; NAS, 'NASPOT 1'1 SPFMV, plants inoculated with Sweetpotato feathery mottle virus; SPCSV, plants inoculated with Sweetpotato chlorotic stunt virus; SPFMV + SPCSV, plants inoculated by both SPFMV and SPCSV.
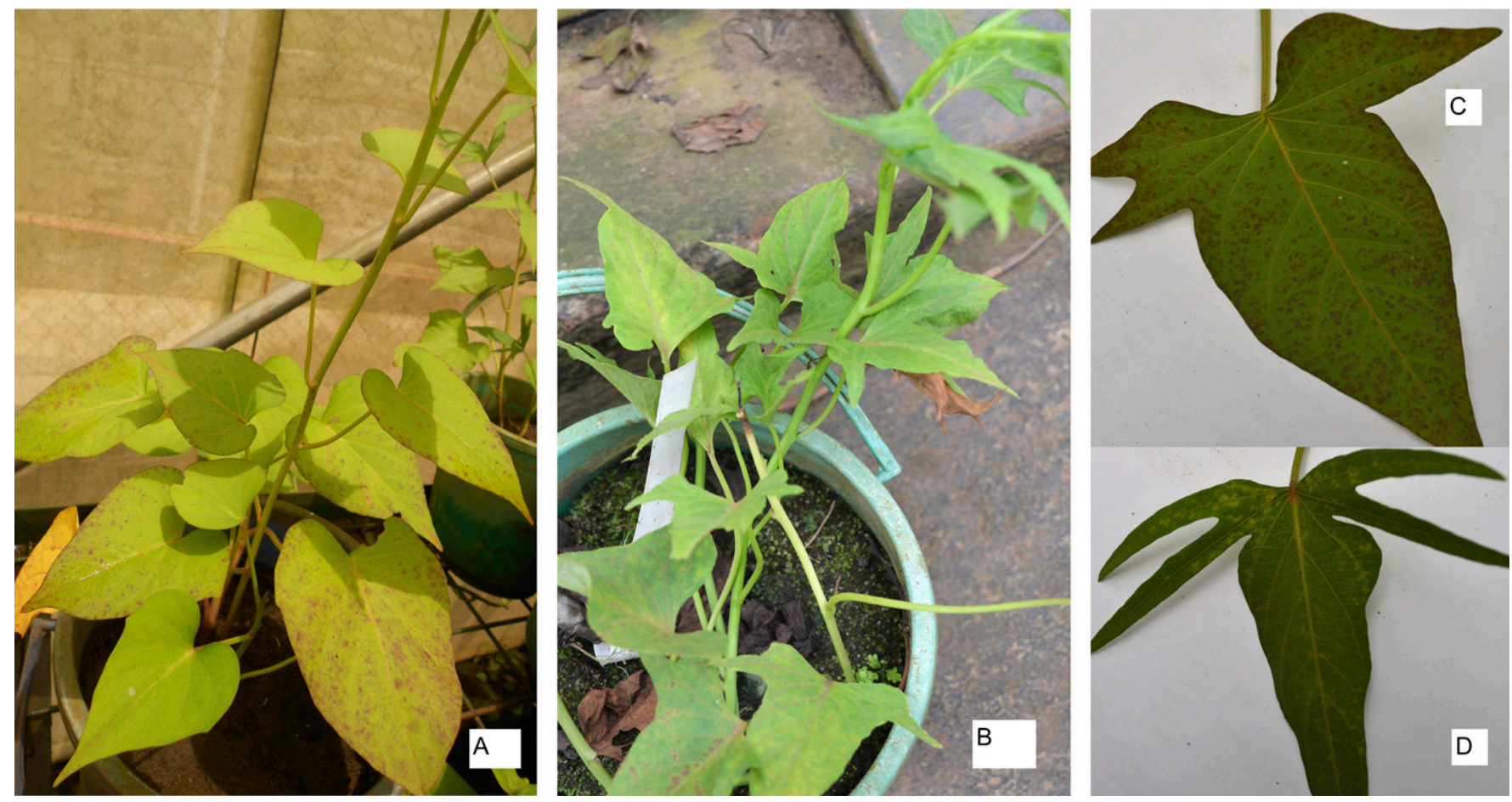

Fig. 5. Virus symptoms on root sprout resulting from infection by Sweetpotato chlorotic stunt virus (SPCSV). (A) Leaf purpling on 'Dimbuka-Bukulula'. (B) Chlorotic spots on 'Ejumula'. (C) Leaf purpling on 'NASPOT 1'. (D) Chlorotic spot on 'Kabode'.

symptoms were very mild and, in some cases, there were no symptoms at all, implying that farmers can be misled easily into using such sprouts as planting material and facilitating the spread of viruses. However, sprouts from roots that are dually infected by SPFMV and SPCSV had very clear symptoms, and can easily be discarded or rogued.

The fact that storage roots can carry viruses has implications for the long-distance spread of these viruses as fresh storage roots are the most marketable product of sweetpotato in Uganda and, as such, are moved from the production site to market and then to the consumer. In each of the stages during which storage roots are moved, farmers may save roots intentionally for further multiplication, especially if the cultivar has the desired qualities. Alternatively, unconsumed storage roots or root wastes such as peelings may sprout, and farmers may use these as planting material when there is scarcity. It has been observed that some farmers plant cultivars with planting material that is available and is not necessarily the preferred cultivar (Hall et al., 1998). Spread of viruses by roots can be worse if the storage roots are from a region with high disease pressure and the status of the mother plant from which the root is obtained is not known. This was supported in this study in which the storage roots that were sampled randomly after harvest from MUARIK all developed symptomatic sprouts that tested positive for both SPFMV and SPCSV. However, in areas such as NaSARRI, with low disease pressure, there was a greater chance of obtaining storage roots with either single virus infection or no infection at all. This finding discourages the use of storage root sprouts with a status that is not clear. Because there are no proper sweetpotato seed channels in Uganda in which clean seed roots are produced and distributed, the use of seed roots can be improved by preselecting the sweetpotato hills/mounds that look apparently healthy to increase the chance of obtaining virus-free seed roots. This is supported by the current study, when selection was made before harvesting but there was still a risk of obtaining storage roots with single infections by either SPFMV or SPCSV. However, as a longterm strategy, there is a need to establish proper seed channels for sweetpotato in which seed stocks are cleaned continuously and made available to the farmers.

In addition to virus symptoms, some storage root sprouts of cultivar NASPOT 1 developed leaf morphology that was different from the mother plant (Fig. 2) and did not test positive for any virus when grafted onto $I$. setosa and when tested by NCM-ELISA. This morphological variation could be the result of a mutation, because the adventitious sprouts obtained from storage roots are much more variable than those produced from meristematic tissues (Villordon and LaBonte, 1996). Such variation may alter genetic combination, resulting in either better or deleterious mutations that 

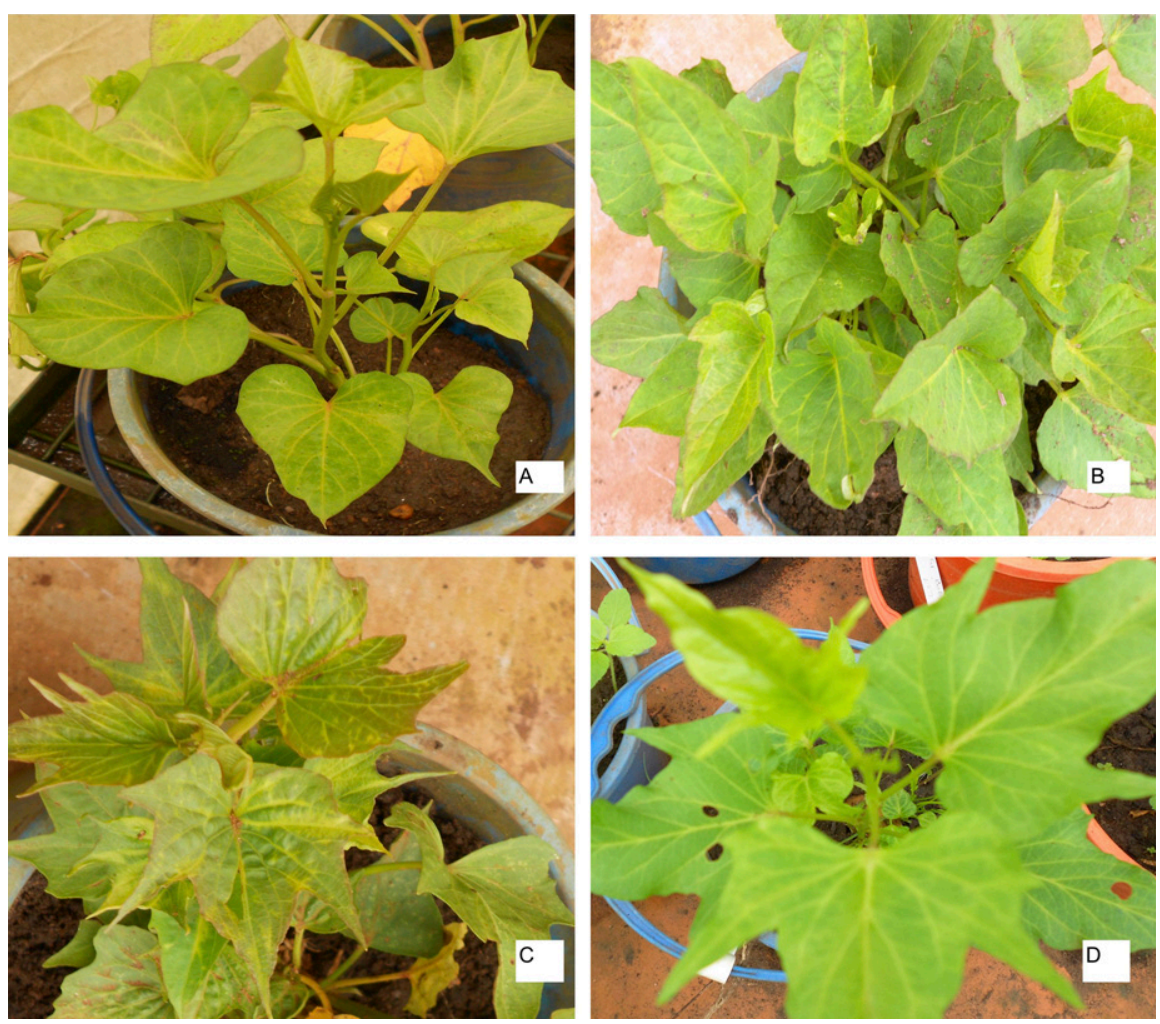

Fig. 6. Symptom expression on root sprout resulting from dual infection by Sweetpotato feathery mottle virus (SPFMV) and Sweetpotato chlorotic stunt virus (SPCSV) (A) Symptoms on 'DimbukaBukulula' (mottling vein clearing, and distorted leaf shape). (B) Symptoms on 'Ejumula' (mottling and vein clearing). (C) Symptoms on 'NASPOT 1' (vein clearing, mottling, and distorted leaf shape). (D) Symptom on 'Kabode' (vein clearing).

Table 4. Proportion of the root sprout that tested positive for Sweetpotato feathery mottle virus (SPFMV) and Sweetpotato chlorotic stunt virus (SPCSV) using enzyme-linked immunosorbent assay.

\begin{tabular}{lcccr}
\hline & \multicolumn{4}{c}{ No. of sprouted roots positive for the virus } \\
\cline { 2 - 5 } Virus & Ejumula & Kabode & Dimbuka-Bukulula & NASPOT 1 \\
\hline SPFMV & $9 / 10$ & $2 / 10$ & $6 / 10$ & $3 / 10$ \\
SPCSV & $6 / 10$ & $2 / 10$ & $5 / 10$ & $3 / 10$ \\
SPFMV + SPCSV & $10 / 10$ & $10 / 10$ & $10 / 10$ & $10 / 10$ \\
\hline
\end{tabular}

Sprouted roots were from roots derived from graft-inoculated plants under screenhouse conditions.

Table 5. Absorbance values from detection of Sweetpotato feathery mottle virus (SPFMV) antigens by double antibody sandwich-enzyme-linked immunosorbent assay and Sweetpotato chlorotic stunt virus (SPCSV) antigens by triple antibody sandwich-enzyme-linked immunosorbent assay in leaves of sprouted roots of cvs. Ejumula, Kabode, Dimbuka-Bukulula, and NASPOT 1, 2, and 5 months after planting (MAP)

\begin{tabular}{|c|c|c|c|c|c|c|}
\hline \multirow[b]{3}{*}{ Cultivar } & \multicolumn{6}{|c|}{ Virus titer } \\
\hline & \multicolumn{3}{|c|}{ SPFMV } & \multicolumn{3}{|c|}{ SPCSV } \\
\hline & $2 \mathrm{MAP}$ & 5 MAP & Negative control & $2 \mathrm{MAP}$ & 5 MAP & $\overline{\text { Negative control }}$ \\
\hline Ejumula & 1.458 & 0.556 & 0.138 & 1.618 & 1.237 & 0.221 \\
\hline Kabode & 0.74 & 0.263 & 0.163 & 0.606 & 0.422 & 0.212 \\
\hline Dimbuka-Bukulula & 0.682 & 0.256 & 0.116 & 0.708 & 0.474 & 0.208 \\
\hline NASPOT 1 & 0.93 & 0.213 & 0.116 & 0.830 & 0.525 & 0.268 \\
\hline
\end{tabular}

may affect sweetpotato yield either positively or negatively. In Uganda, the use of storage root sprouts is not common, but with the current effort by CIP to promote use of storage root sprout, especially in dry areas, there is a need to determine the consequent rate of mutations in Ugandan sweetpotato cultivars. Alternatively, the morphological leaf variation could also be a result of an unknown virus for which tests are not available.
Also, some storage roots derived from plants infected singly by SPCSV or SPFMV did not show any virus symptoms on the sprouts and also tested negative when grafted onto I. setosa and tested using ELISA. Similar findings were reported in potato, in which some infected plants produced virusfree potato tubers, which produce virus-free shoots (Wilson, 2001). The mechanism by which infected sweetpotato plants can produce healthy storage roots is not fully un- derstood and requires further investigation. Failure to detect viruses from storage root sprouts derived from infected plants could be because of low virus titers that could not be detected by ELISA. There is the need to use a more sensitive method, such as real-time quantitative polymerase chain reaction to conclude more fully that the roots indeed were not infected.

This study showed that storage root sprouts infected singly with SPFMV can revert to a healthy status in both moderately resistant cultivars such as NASPOT 1, moderately susceptible cultivars such as DimbukaBukulula, and susceptible ones such as Ejumula, as evidenced by the drastic reduction in virus titer. Similar results have been reported in most Ugandan landraces and station-bred cultivars that have varying levels of resistance (Aritua et al., 1998; Gibson et al., 1997, 2014; Wasswa 2012). This explains why some symptomless vines in farmers' fields appeared to be virus free (Gibson et al., 1997). The reversion also seems to influence the selection of a given cultivar for a given region. For example, 'NASPOT 1', which is moderately resistant and demonstrates quick reversion, is widely grown in central Uganda, which has high disease pressure. This result agrees with that of Gasura et al. (2009), that cultivars with the ability to recover were common in the high-SPVD pressure zones in central and western regions of Uganda. Also, the reversion of most Ugandan cultivars from SPFMV infection makes it easier to clean infected plants through meristem tip culture and thermotherapy (Rukarwa et al., 2010). On the other hand, no cultivar reverted from SPCSV, although there was reduction in virus titer by the fifth month after sprouting. Lack of reversion by SPCSV-infected plants was also observed under field conditions (Adikini et al., 2016), which makes SPCSV a limiting factor in cleaning sweetpotato planting material; although in some cultivars, infected plants can easily be identified visually by symptoms. This agrees with the work of Rukarwa et al. (2010), who did not obtain any virus-cleaned material from plants infected with SPCSV when subjected to meristem tip culture and thermotherapy.

Among the cultivars tested under screenhouse conditions, Ejumula was the most susceptible to all the viruses tested in both single and mixed infections because most of them were able to develop symptoms but also tested positive with ELISA. This finding is similar to earlier work under field conditions (Adikini et al., 2016). Cultivars NASPOT 1, Dimbuka-Bukulula, and Kabode showed moderate resistance to single virus infection, and the resistance broke down in response to mixed infections of SPFMV + SPCSV as reported previously (Adikini et al., 2016; Miano, 2008). In terms of yield effect, mixed infections severely reduced the yield of all the cultivars tested followed by infection by SPCSV, and least in SPFMV, which is similar to the trends observed under field conditions (Adikini et al., 2016), although the root yield performance under screenhouse conditions was 
Table 6. Mean number of root sprouts produced by different sweetpotato cultivars infected with Sweetpotato feathery mottle virus (SPFMV) and Sweetpotato chlorotic stunt virus (SPCSV) under screenhouse conditions.

\begin{tabular}{lcccc}
\hline & \multicolumn{4}{c}{ Mean no. of sprouts/root } \\
\cline { 2 - 5 } Virus & Ejumula & Kabode & Dimbuka-Bukulula & NASPOT 1 \\
\hline Healthy & $4.5 \mathrm{a}$ & $4.6 \mathrm{a}$ & $3.3 \mathrm{~b}$ & $3.5 \mathrm{ab}$ \\
SPFMV & $4.8 \mathrm{a}$ & $4.2 \mathrm{a}$ & $5.9 \mathrm{a}$ & $3.9 \mathrm{a}$ \\
SPCSV & $5.1 \mathrm{a}$ & $4.2 \mathrm{a}$ & $4.4 \mathrm{ab}$ & $4.4 \mathrm{a}$ \\
SPFMV + SPCSV & $4.5 \mathrm{a}$ & $3.7 \mathrm{a}$ & $2.2 \mathrm{~b}$ & $2.8 \mathrm{~b}$ \\
\hline
\end{tabular}

Means within a column followed by the same letter are not significantly different $(P<0.05)$ according to Fisher's protected least significant difference.

very poor compared with yield under field conditions.

This study has clearly demonstrated that once sweetpotato vines get infected with any virus, whether single or a combination of infections, these viruses are capable of infecting storage roots of Ugandan sweetpotato cultivars that, if used as seed root, will produce infected sprouts, leading to virus spread. If infection is by single virus, storage root sprouts may produce mild or no symptoms, and the sprout has the ability to recover from virus infection in the case of SPCSV, or the ability to revert to normal in the case of SPFMV. For dual infection with SPFMV and SPCSV, no reversion occurs. Instead, root sprouts produce very clear symptoms; therefore, farmers can easily rogue such seed roots at early stages of sprouting. Such infected roots, if used as planting material, will only increase the spread of viruses if vectors are present. It is therefore important for farmers to select the seed roots from disease-free plants by prior selection of mother plants before harvesting. Selecting seed roots from already harvested sweetpotato or from roots bought at the market or from neighbors without knowing the status of the mother plant should be discouraged. There is a need for developing means of multiplication of seed roots as a long-term measure for ensuring continuous production and supply of sweetpotato, especially in areas prone to drought.

\section{Literature Cited}

Adikini, S., S.B. Mukasa, R.O.M. Mwanga, and R.W. Gibson. 2016. Effects of Sweet potato feathery mottle virus and Sweet potato chlorotic stunt virus on the yield of sweetpotato in Uganda. J. Phytopathol. 164:242-254.

Aritua, V., T. Alicai, E. Adipala, E.E. Carey, and R.W. Gibson. 1998. Aspects of resistance to sweet potato virus disease in sweet potato. Ann. Appl. Biol. 132:387-398.

Aritua, V., B. Bua, E. Barg, H.J. Vetten, E. Adipala, and R.W. Gibson. 2007. Incidence of five viruses infecting sweet potatoes in Uganda: The first evidence of Sweet potato caulimo-like virus in Africa. Plant Pathol. 56:324-331.

Aritua, V., E. El-BedeOwy, M.O. Lanya, and P. Ewel. 2000. Yield and reaction of non-indigenous sweetpotato clones to sweetpotato virus disease in Uganda, p. 48-54. In: Y. Nakazawa and K. Ishiguro (eds.). Proceedings of the $1^{\text {st }}$ International Workshop on Sweetpotato Cultivar Decline Study, 8-9 Sept. 2000. Miyazaki, Miyakonojo, Japan.

Bashaasha, B., R.O.M. Mwanga, C. Ocitti p'Obwoya, and P.T. Ewell. 1995. Sweet potato in the farming and food systems of Uganda: A farm survey report. International Potato Center (CIP) and National Agricultural Research Organization (NARO), Lima, Peru.

Clark, C.A. and J.W. Moyer. 1988. Compendium of sweet potato diseases. The Amer. Phytopathol. Soc. 12:93-101.

Clark, C.A. and M.W. Hoy. 2006. Effects of common viruses on yield and quality of Beauregard sweet potato in Louisiana. Plant Dis. 90:83-88.

Clark, F.M. and A.N. Adams. 1977. Characteristics of the microplate method of enzyme linked immunosorbent assay for detection of plant viruses. J. Gen. Virol. 34:475-483.

Fargette, D., J.M. Thresh, and G.W. Otim-Nape. 1994. The epidemiology of African cassava mosaic geminivirus: Reversion and the concept of equilibrium. Trop. Sci. 34:123-133.

Gasura, E., A.B. Mashingaidze, and S.B. Mukasa. 2009. Occurrence, prevalence and implications of sweetpotato recovery from sweetpotato virus disease in Uganda. Afr. Crop Sci. Conf. Proc. 9:601-608.

Gibson, R.W., I. Mpembe, T. Alicai, E.E. Carey, R.O.M. Mwanga, S.E. Seal, and H.F. Vetten. 1998. Symptoms, aetiology, and serological analysis of sweetpotato virus disease in Uganda. Plant Pathol. 47:95-102.

Gibson, R.W., R.O.M. Mwanga, S. Kasule, I. Mpembe, and E.E. Carey. 1997. Apparent absence of viruses in most symptomless fieldgrown sweetpotato in Uganda. Ann. Appl. Biol. 130:481-490.

Gibson, R.W., R.O.M. Mwanga, S. Namanda, S.C. Jeremiah, and I. Barker. 2009. Review of sweetpotato seed systems in East and Southern Africa. Integrated Crop Management Working Paper 2009-1/ International Potato Center (CIP), Lima, Peru.

Gibson, R.W., S. Namanda, and K. Sindi. 2011. Sweetpotato seed systems in East Africa. J. Crop Improv. 10:449-451.

Gibson, R.W. and G.W. Otim-Nape. 1997. Factors determining recovery and reversion in mosaicaffected African cassava mosaic virus infected cassava. Ann. Appl. Biol. 131:259-271.

Gibson, R.W., P. Wasswa, and H.A. Tufan. 2014. The ability of cultivars of sweetpotato in East Africa to 'revert' from sweet potato feathery mottle virus infection. Virus Res. 186:130-134

Gutierrez, D.L., S. Fuentes, and L. Salazar. 2003. Sweetpotato virus disease (SPVD): Distribution, incidence, and effect on sweet potato yield in Peru. Plant Dis. 87:297-302.

Hall, A.J., G.N. Bockett, and S. Nahdy. 1998. Sweet potato post-harvest systems in Uganda: Strategies constraints and potentials. International Potato Centre (CIP) Social Science Department Working Paper Series No. 1998-7. CIP, Lima, Peru.

Karyeija, R.F., R.W. Gibson, and J.P.T. Valkonen. 1998. The significance of sweetpotato feathery mottle virus in subsistence sweetpotato production in Africa. Plant Dis. 82:4-15.

Miano, W.D. 2008. Replication of viruses responsible for sweet potato virus disease in resistant and susceptible sweetpotato genotypes and identification of molecular markers linked to resistance. Louisiana State University and Agricultural and Mechanical College, PhD Diss.

Milgram, M., J. Cohen, and G. Loebenstein. 1996. Effects of sweet potato feathery mottle virus and sweet potato sunken vein virus on sweet potato yields and rates of reinfection of virusfree planting material in Israel. Phytoparasitica 24:189-193.

Mukasa, S.B., P.R. Rubaihayo, and J.P.T. Valkonen. 2003. Incidence of viruses and virus-like diseases of sweet potato in Uganda. Plant Dis. 87:329-335.

Mwanga, R.O.M., B. Odongo, C. Niringiye, and A. Alajo. 2007. Release of two orange-fleshed sweetpotato cultivars, 'SPK004 ('Kakamega') and 'Ejumula', in Uganda. Hort. Sci. (Prague) 42:1728-1730.

Mwanga, R.O.M., B. Odongo, G. Turyamureeba, A. Alajo, G.C. Yencho, R.W. Gibson, N.E.J.M. Smit, and E.E. Carey. 2003. Release of six sweet potato cultivars ('NASPOT 1' to 'NASPOT 6') in Uganda. Hort. Sci. (Prague) 38:475-476.

Mwanga, R.O.M., G.C. Yencho, R.W. Gibson, and J.W. Moyer. 2013. Methodology for inoculating sweetpotato virus disease: Discovery of tip dieback, and plant recovery and reversion in different clones. Plant Dis. 97:30-36.

Namanda, S. 2012. Current and potential systems for maintaining sweetpotato planting material in areas with prolonged dry season: A biological, social and economic frame work. University of Greenwich, PhD Diss.

Namanda, S., R. Gibson, and K. Sindi. 2011. Sweetpotato seed systems in Uganda, Tanzania and Rwanda. J. Sustain. Agr. 35(8):870-884.

Ndunguru, J., R. Kapinga, P. Seruwagi, B. Sayi, R.O.M. Mwanga, S. Tumwegamire, and C. Rugutu. 2009. Assessing the sweetpotato virus disease and its associated vectors in northwestern Tanzania and central Uganda. Afr. J. Agr. Res. 4:334-343.

Rukarwa, R.J., A.B. Mashingaidzel, S. Kyamanywa, and S.B. Mukasa. 2010. Detection and elimination of sweetpotato viruses. Afr. Crop Sci. J. 18: 223-233.

Villordon, A.Q. and D.R. LaBonte. 1996. Genetic variation among sweetpotatoes propagated through nodal and adventitious sprouts. J. Amer. Soc. Hort. Sci. 121:170-174.

Wasswa, P. 2012. Sweetpotato viruses in Uganda: Identification of a new virus, a mild strain of an old virus and reversion. University of Greenwich, $\mathrm{PhD}$ Diss.

Wasswa, P., B. Otto, M.N. Maruthi, S.B. Mukasa, W. Monger, and R.W. Gibson. 2011. First identification of a sweet potato begomovirus (sweepovirus) in Uganda: Characterization, detection and distribution. Plant Pathol. 60:1030-1039.

Wilson, C.R. 2001. Resistance to infection and translocation of tomato spotted wilt virus in potatoes. Plant Pathol. 50:402-410.

Yanggen, D. and S. Nagujja. 2006. The use of orange fleshed sweetpotato to combat vitamin A deficiency in Uganda: A study of varietal preferences, extension strategies and postharvest utilization. Social Sciences Working Paper No. 2006-2. The International Potato Centre, Lima, Peru. 